\title{
THE RELATION BETWEEN GLUCOSE UTILIZATION, LACTIC ACID PRODUCTION AND UTILIZATION AND THE GROWTH CYCLE OF L STRAIN FIBROBLASTS ${ }^{1}$
}

\author{
W. H. MUNYON and D. J. MERCHANT \\ Department of Bacteriology, The University of Michigan Medical School, Ann Arbor, Mich., U.S.A.
}

Received November 19, 1958

Carbonydratr: metabolism of tissue cultures has been studied extensively $[1,3,4,9,10,12,14,19,21,22,24,25,26]$. Experimental methods applied have varied from primary explants embedded in plasma clots [25], to stable strains of cells growing in massive suspension cultures [3]. Several points emerge from such studies. Among these are: $(a)$ cells in vitro may metabolize glucose either aerobically or anaerobically $[12,14],(b)$ glucose uplake and glycolysis are rapid during the early stages of growth; a high glycolytic rate is sustained when glucose is maintained at a high level $[3,10,25,26],(c)$ glucose uptake is proportional to glucose concentration only in the higher ranges $(2-4 \mathrm{mg} / \mathrm{ml})$ of glucose concentration $[10,14,25],(d)$ after an initial rapid increase in lactic acid concentration in the medium, lactate may decrease $[18,26]$ though no clear pattern of lactate utilization is apparent.

In recent years major advances have been made in our knowledge of the growth of animal cells in vilro. One such development has been the description of population growth in terms well established in microbiology [15]. Though nucleic acid and protein synthesis has been related to population development $[6,16]$, little has been done to make such correlations with carbohydrate metabolism. While Bryant and co-workers [3] have made measurements of glucose and lactate levels along with nuclei counts, their methods, particularly with regard to medium renewal make interpretation difficult.

In the present paper the authors have attempted to follow carbohydrate metabolism by measurements of glucose and lactate levels at successive periods of growth and to correlate the patterns obtained, with growth curves based on cell numbers and on packed cell volume. It is thus possible to deter-

1 This work was supported by grant 383 from the Horace H. Rackham School of Graduate Studies, The University of Michigan, and by a grant from Parke, Davis and Company, Detroit, Michigan. 
mine whether a relationship exists between various phases of population development and changes in overall carbohydrate metabolism. By calculating glucose and lactate changes on a per cell basis, we have demonstrated that glucose utilization is more closely related to changes in cell size than to cell numbers.

Evidence is presented to support the contention that lactate is utilized after an initial period of rapid lactic acid production. Contrary to the findings of Wilson et al. [26], this is shown to occur when appreciable amounts of glucose remain in the medium. Subsequently, when glucose levels are lower, there is a secondary period of lactate accumulation.

\section{MATERIALS AND METHODS}

The cells used in these experiments were $L$ strain 929 mouse fibroblasts [20]. The stock cells were cultivated under the same conditions and in the same medium as the experimental cultures. The cell concentration of the stock cultures at the time subcultures were made was $1.5 \times 10^{5}$ cells per $\mathrm{ml}$. The medium used contained 0.5 g yeast extract, $2.5 \mathrm{~g}$ lactalbumin hydrolysate and $5.0 \mathrm{~g}$ Bact-peptone per liter in Hank's BSS [11]. To this base was added Eagle's basic vitamin and amino acid mixtures [7] at one-half strength and sufficient penicillin and streptomycin to give a final concentration of 100 units and $100 \mu \mathrm{g}$ per ml, respectively. The above medium was supplemented with 5 per cent by volume of whole horse serum. The initial concentration of glucose was $1 \mathrm{mg}$ per $\mathrm{ml}$ and of lactate was $50 \mu \mathrm{g}$ (the latter was contributed by the addition of horse serum). A volume of $210 \mathrm{ml}$ of cell suspension was placed in each of four $500 \mathrm{ml}$ erlenmeyer flasks which were closed with rubber stoppers. The atmosphere overlying the cultures was air. The cultures were not gassed either continuously or intermittantly. They were agitated on a rotary action shaker at $100 \mathrm{rpm}$. The temperature of incubation was $35^{\circ} \mathrm{C} \pm 1.5^{\circ} \mathrm{C}$.

A $13 \mathrm{ml}$ sample was withdrawn from each culture at approximately $24 \mathrm{hr}$ intervals for the purpose of making cell counts, chemical analyses and $\mathrm{pH}$ measurements. $\mathrm{pH}$ was determined with a model $\mathrm{G}$ Beckman $\mathrm{pH}$ meter using $1.5 \mathrm{ml}$ of the sample. This measurement was accomplished within 30 seconds of the opening of each flask to avoid $\mathrm{pH}$ shift due to loss of $\mathrm{CO}_{2}$. A $10 \mathrm{ml}$ aliquot was pipetted into a Hopkins tube graduated to $0.002 \mathrm{mI}$ and was centrifuged at $650 \mathrm{~g}$ for 10 minutes to determine the packed cell volume (PCV). The remaining $1.5 \mathrm{ml}$ of the sample was used to make cell counts with a haemocytometer. The supernatant fluid from the PCV determination was frozen and saved for chemical analyses. Lactic acid concentrations were determined by the method of Barker and Summerson [2] and glucose concentrations by a colorimetric glucose oxidase method [13]. The rates of glucose uptake and lactic acid uptake or production per cell per hour were computed from the changes in concentration of the respective substances, the average cell number during the time interval and the time elapsed during the interval. Average cell size was computed from the ratio of the PCV to the number of cells per ml.

\footnotetext{
1 Eberbach and Son Company, Ann Arbor, Michigan.
} 


\section{RESULTS}

Four experimental flasks and one control flask without cells were used in these experiments. The latter was included to determine the effect of serum enzymes on the glucose and lactate concentrations. In this control the glucose concentration remained constant while the lactate concentration dropped from

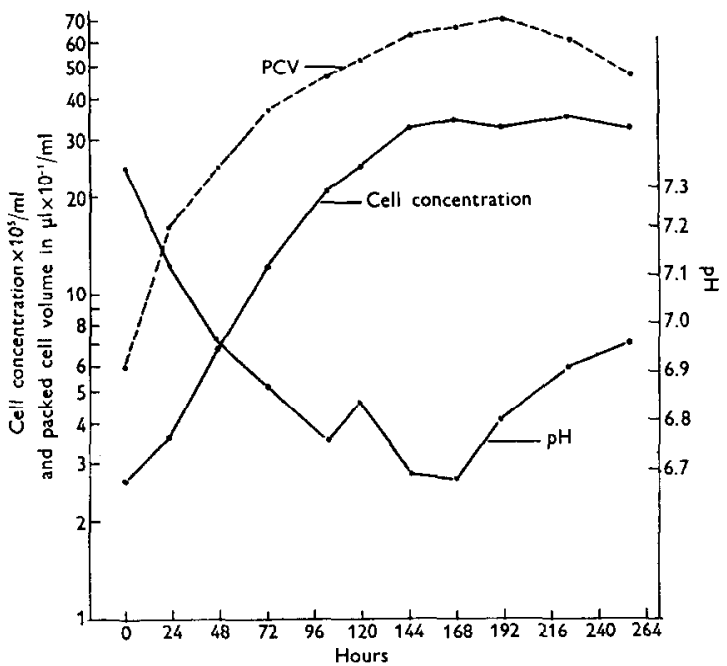

Fig. 1.-Growth curve of $L$ strain fibroblasts in suspension.

50 to $46 \mu \mathrm{g}$ per $\mathrm{ml}$, during the five day test period. The data from studies of the four replicate cultures are presented in Figs. 1, 2 and 3 and in Table I. As shown by the graph of cell numbers in Fig. 1, during the first $101 \mathrm{hrs}$ of culture, the cells were in a state of rapid logarithmic division. The PCV (dashed line) rose during this interval, but did not parallel the increase in cell number; in particular, it is not linear during the period of linear increase in cells numbers. The line graph of Fig. 3 represents changes in average cell volume derived from the different rates of growth as measured by cell concentrations and packed cell volumes. The $\mathrm{pH}$ of the medium decreased from 7.3 to 6.8 during the period of linear increase in cell numbers.

As seen in Fig. 2, lactate accumulated in the medium, and the rate of glucose uptake per cell was rapid during the $0-47 \mathrm{hr}$ interval. In the $47-101 \mathrm{hr}$ interval, lactate was rapidly taken up from the medium so that the concentration was reduced to $27 \mu \mathrm{g}$ per $\mathrm{ml}$ at $101 \mathrm{hrs}$. During this period of lactate uptake, it is significant that the $\mathrm{pH}$ continued to decrease, the glucose concentration 
dropped from 0.63 to $0.46 \mathrm{mg}$ per $\mathrm{ml}$ and the rate of glucose uptake was much slower than during the $0-24 \mathrm{hr}$ or the $24-47 \mathrm{hr}$ intervals.

Lactate accumulated in the medium again during the 117-144 $\mathrm{hr}$ period, while both the rate of glucose uptake and the concentration of glucose in the medium were less than they had been during the $0-47 \mathrm{hr}$ interval. This second period of lactate accumulation occurred when the cells were approach-

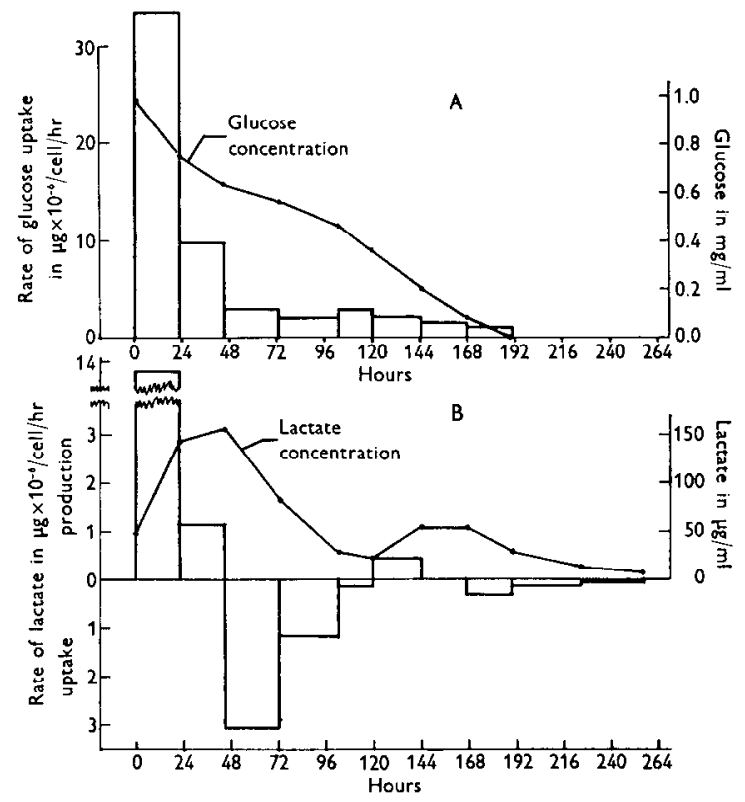

Fig. 2.-A: Glucose and lactate levels in suspension cultures of $\mathrm{L}$ strain fibroblasts. The line graph represents the concentration of glucose in the medium in $\mathrm{mg}$ per $\mathrm{ml}$; the histogram represents the average rate of glucose uptake per cell per hour. $B$ : The line graph represents the concentration of lactate in the medium in $\mu \mathrm{g}$ per ml; the histogram shows above the abscissa, the rate of lactate production per cell per hour and, below the abscissa, the rate of lactate uptake per cell per hour.

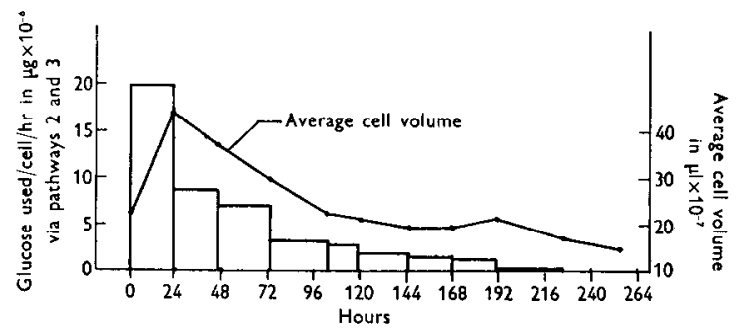

Fig. 3.-Relationship of cell mass to carbohydrate metabolism. The line graph represents the average cell volume. The histogram represents the effective amount of glucose used per cell per hour for conversion to amino acids or other carbohydrates or organic acids (pathway 2) or oxidation (pathway 3). 
ing the stationary phase of growth. Glucose was entirely exhausted from the medium after $190 \mathrm{hrs}$; lactate was slowly taken up during the 168-267 hr interval, but was never exhausted from the medium.

TABLE I. The relationship between glucose utilization and glucose concentration in the medium.

\begin{tabular}{|c|c|c|}
\hline $\begin{array}{l}\text { Interval } \\
\text { in hours }\end{array}$ & $\begin{array}{l}\text { Range of } \\
\text { glucose cone. } \\
\text { in } \mathrm{mg} / \mathrm{ml}\end{array}$ & $\begin{array}{l}\text { Glucose uptake in } \mu \mathrm{g} \times-6 / \mathrm{cell} / \mathrm{hr} \\
\text { Average glucose conc. in } \mathrm{mg} / \mathrm{ml}\end{array}$ \\
\hline $0-24$ & $0.97-0.74$ & 38.8 \\
\hline $24-47$ & $0.74-0.63$ & 14.2 \\
\hline $47-72$ & $0.63-0.56$ & 4.9 \\
\hline $72-101$ & $0.56-0.46$ & 3.9 \\
\hline $101-117$ & $0.46-0.36$ & 6,8 \\
\hline $117-144$ & $0.36-0.20$ & 7.9 \\
\hline $144-168$ & $0.20-0.08$ & 10.7 \\
\hline $168-190$ & $0.08-0.00$ & 25.0 \\
\hline
\end{tabular}

The ratio between the rate of glucose uptake during a given interval of time and the fall in the glucose concentration during that interval are listed in Table I. During the first three days of culture the ratio decreased because of the more rapid decrease in the rate of glucose uptake than in glucose concentration. From this it can be seen that glucose uptake per cell was not proportional to the glucose concentration, between 0 and $1 \mathrm{mg}$ per $\mathrm{ml}$.

\section{DISCUSSION}

In our studies the high initial rates of glucose uptake and of lactate production (first $24 \mathrm{hrs}$ ) and the following rapid decrease in these rates were similar to the findings of Willmer [25], Wilson et al. [26]; however, the actual concentrations of lactate accumulated in the medium were different. This is undoubtedly due in part to the difference in cells and in medium used in the two sets of experiments.

The uptake of lactate during the latter half of the log phase of growth, when the glucose concentration had fallen to only 50 per cent of its initial level, was an unexpected result. Previous data had indicated that lactate was used only when the concentration of glucose was low. In the work reported here, however, oxidative metabolism was used even though glycolysis was 
apparently an available pathway. This is in agreement with the finding by Phillips and Feldhaus [19] that aerobic glycolysis was low in L strain fibroblasts. In a subsequent experiment, to see if this pattern of oxidative metabolism would continue after subculture, cells from a culture in the log growth phase (when lactate was being utilized) were inoculated into fresh medium. These cells reverted to a glycolytic pattern similar to that noted during the first day of culture in the previous experiment. This is probably the same effect noted by Wilson et al. [26], i.e. that a high rate of glycolysis could be maintained by renewing the medium daily to maintain a high glucose level. It also indicates that in this case the pattern of cell metabolism is more directly related to the composition of the medium than to any other factor.

The observation that $\mathrm{pH}$ decreased during the interval when the lactate concentration of the medium was decreasing indicates that factors other than lactate accumulation must be responsible for medium acidification during that interval. The decrease in lactic acid concentration would, in itself, raise the $\mathrm{pH}$. It has been reported by Fisher and Ginsberg [8] that several other organic acids accumulate in the medium during growth of HeLa cells. It is therefore possible that these acids are depressing the $\mathrm{pH}$. However Westfall [24] and Jones [14] found that these acids, such as pyruvic or keto glutaric did not accumulate in the medium in appreciable quantities.

Lactate again began to accumulate in the medium as the cultures neared the plateau of growth. This increase in lactate concentrations, observed in all flasks and in subsequent experiments, rose from about $25 \mu \mathrm{g}$ to between 50 and $80 \mu \mathrm{g}$ per $\mathrm{ml}$. This is consistent with previous findings that the rate of lactate accumulation increased when growth was poor or slowing down $[17,26]$. The resumption of glycolysis was a surprising occurrence in view of the fact that the glucose concentration had been reduced to between one third and one fifth of the initial concentration and that lactate had been utilized earlier in the presence of higher glucose levels. The significance of this resumption of glycolysis is not known at present.

A comparison of the rate of glucose uptake with growth as measured by cell numbers shows that there is no constant relation between the two. Therefore, in an effort to obtain a more complete measure of carbohydrate metabolism, a combined value of the rates of glucose and lactate metabolism has been computed. For this purpose, the metabolism of glucose can be subdivided into three mechanisms: (1) conversion to lactate, (2) incorporation into other carbohydrates or into amino or organic acids, (3) oxidation to $\mathrm{CO}_{2}$ and $\mathrm{H}_{2} \mathrm{O}$.

Several publications dealing with the carbohydrate metabolism of tissue 
cultures have presented information which indicates that lactate accumulates in the medium as the result of glucose break down $[14,21]$. It has been observed that only small amounts of lactate are produced when glucose is excluded from the medium of chick-heart fibroblasts [12]. Similar results have been obtained with chick lung and intestine [14]. Wilson et al. [26] found that when glucose was excluded from a synthetic medium plus Witte peptone, urea and $\mathrm{NH}_{3}$ production accounted for the amino acid utilized, indicating that amino acids were oxidized. However, this was not true when glucose was available, indicating a failure to oxidize amino acids in the presence of glucose. In a similar experiment with embryonic kidney, urea and $\mathrm{NH}_{3}$ production ceased when glucose was added to the medium [23]. Thus it is assumed that when glucose is present in the medium, lactate results from the conversion of glucose, the amount of glucose converted into lactate can be computed. If this amount is subtracted from the total amount of glucose taken up during any period, the amount of glucose that was used via pathways 2 and 3 (see above) can be computed. A correction must be applied to these calculations for the lactate taken from the medium during some intervals. This is justifiable on the basis that lactate will have the same fate as glucose metabolized by pathways 2 and 3 .

The histogram in Fig. 3 represents the algebraic sum of the amounts of glucose taken up per cell per hour and the glucose equivalent of the lactate taken up or produced per ecll per hour. The total is equal to the effective amount of glucose metabolized by pathways 2 and 3. This histogram can be considered as an index of cell carbohydrate metabolism, since glucose is the most important carbohydrate substrate in the medium. When fig. $f$ is compared with Fig. 1, it can be seen that in this experiment there was no constant relationship between cell growth as measured by increases in cell numbers and the rate of carbohydrate metabolism in contrast with the findings of Fulton et al. [9]. However, when the rate of cell carbohydrate metabolism is compared with average cell size, as in Fig. 3, it can be seen that when the average cell volume doubled during the $0-24 \mathrm{hr}$ interval, the rate of carbohydrate netabolism was very high, and that the rate of carbohydrate metabolism per cell decreased thereafter as the average cell volume decreased. It is of interest to note that during the period of logarithmic growth, when the generation time was constant, succeeding generations of cells were progressively smaller in size. Thus no constant relationship existed between synthesis required for cell division and the increase of packed cell volume. Davidson et al. [6], using chick embryo explants, report that during the $0-48 \mathrm{hr}$ period lipid phosphorus, acid soluble protein and RNA phosphorus all increased per cell, 
and that from 48-72 hrs the acid soluble protein and RNA continued to increase but at a decreasing rate. After this, all these cell constituents were observed to fall sharply even though cell division continued to be rapid. Under the conditions of this experiment, carbohydrate metabolism appeared to be more intimately associated with increases in packed cell volume than with increases in cell number and it is hypothesized that the rate of carbohydrate metabolism is directly related to mean cell volume. These findings are in agreement with those reported by Corbett [5] for bacteria and protozoa.

\section{SUMMARY}

1. Glucose and lactate metabolism of L strain fibroblasts growing in an agitated suspension was correlated with the growth phase of the culture and with changes in the average cell volume and $\mathrm{pH}$ changes in the medium.

2. In agreement with previous work, it was found that the rate of glucose uptake and lactate production was most rapid during the first part of the logarithmic growth period. It was found, however, that lactate was taken up by the cells when glucose was still present in relatively high concentrations. During the last half of the logarithmic growth period, lactate was rapidly taken up and the rate of glucose uptake was low. Lactate was found to accumulate in the medium for the second time as the cultures entered the plateau phase of growth. Later in the plateau phase, lactate was reduced to very low values and glucose was exhausted from the medium after 192 hrs.

3. From the observation that the $\mathrm{pH}$ decreased while lactate decreased in concentration it was concluded that other factors causing $\mathrm{pH}$ depression must have been functioning at that time.

4. A calculation of the rate of cell carbohydrate metabolism indicated that there was no constant relation between the rate of carbohydrate uptake per cell and the rate of mitosis during progressive intervals of the growth cycle. It is hypothesized that the rate of cell carbohydrate metabolism is directly related to average cell volume.

The authors are indebted to Dr. J. F. Hogg, of the Department of Biological Chemistry and to Dr. H. J. Blumenthal of the Department of Bacteriology, at The University of Michigan, for their suggestions in this work.

\section{REFERENCES}

1. Barban, S. and Schulze, H., J. Biol. Chem. 222, 665 (1956).

2. Barker, S. and Summerson, W., J. Biol. Chem. 138, 535 (1941).

3. Bryant, J., Schilling, E. and Earle, W., J. Natl. Cancer Inst. 21, 349 (1958). 
4. Chang, R. and Geyer, R., Proc. Soc. Exptl. Biol. and Med. 96, 336 (1957).

5. Conbett, J., J. Cellular and Comp. Physiol. 50, 309 (1957).

6. Davidson, J. and Lesile, I., Exptl. Cell Researeh 2, 366 (1951).

7. EAGLE, H., Science 122, 501 (1955).

8. Fisher, T. N. and Ginsberg, H. S., Proc. Soc. Exptl. Biol. Med. 95, 47 (1957).

9. Fulton, W., Sinclair, R. and Leslie, I., Biochem. J. 63, 18p (1956).

10. Gemmill, C., Gey, G., and Austrian, R., Bull. Johns Hopkins Hosp. 66, 167 (1940).

11. Hanks, J. and Wallace, R., Proc. Soc. Exptl. Biol. Med. 71, 196 (1949).

12. Harris, M. and Kutsky, P., J. Cellular Comp. Physiol. 42, 449 (1953).

13. Huggett, A. and Nixon, D., Biochem. J. 66, 12p (1957).

14. Jones, M. and Bonting, S., Exptl. Cell Research 10, 631 (1956).

15. Kughler, R. and Merchant, D., Proc. Soc. Expll. Biol. Med. 92, 803 (1956).

16. - Univ. Mich. Med. Bull. 24, 200 (1958).

17. Meier, R., Biochem. $Z .231,253$ (1931).

18. Paul, J. and Pearsox, E., Biochem. J. 63, 16p (1956).

19. Phillips, H. and Feldhaus, R., Proc. Soc. Expll. Biol. Med. 92, 478 (1956).

20. Sanford, K., Earle, W. and Likely, G., J. Natl. Cancer Inst. 9, 229 (1948).

21. Suschny, O., Kellner, G., Broda, E., Figdor, B. and Rücker, W., Expll. Cell Research 14, $316(1958)$.

22. Warburg, O. and Kubowitz, F., Biochem. Z. 189, 242 (1927).

23. Watchhorn, E, and Holmes, E., J. Biochem. 21, 139 (1927).

24. Westafll, B., Peppers, E. and Earle, E., Am. J. Hygiene 61, 326 (1955).

25. Willmer, E., J. Expll. Biol. 18, 237 (1941-1942).

26. Wilson, H., Jackson, E. and Brues, A., J. Gen. Physiol. 25, 689 (1941-1942). 